\title{
Diversity Of Desired And Observed Levels Of Qualities Among Teacher Candidates Perceived By Private School Management
}

Muhammad Imran Yousuf, PMAS Arid Agriculture University, Pakistan Naveed Sultana, AIOU, Pakistan

Muhmmad Naseer-ud-Din, KUST, Pakistan

Sajid Rehman, UIER, Rawalpindi, Pakistan

\begin{abstract}
The trend of enrolment in private schools is growing rapidly. The criteria of quality for teacher candidates is complex one, great value is placed for oral interviews along with other formal techniques of selection process. The present study focused to investigate the desired and observed levels of qualities for teacher candidates perceived by their employers at private educational institutions in Pakistan. Interviews of personnel involved in selection process, a focus group discussion and a survey were used as the research method. After semi-structured interview with 20 employers the initial three levels of dimensions of qualities for teacher candidates i.e. dimensions of educational and professional knowledge; dimensions of teaching and professional skills; and dimensions of values and attitudes were developed and kept for focus group discussion. In this way six qualities for each dimension were finalized and the survey was conducted to rate the desired and observed levels of 18 items. A total number of 139 responses were available through this survey. The mean of desired and observed responses for each item was calculated. The difference between means, standard deviations and t-values were also calculated. The differences in mean values for desired and observed levels for all three categories indicate that employers of private schools are not satisfied with the output of teachers training programs.
\end{abstract}

Keywords: Teacher candidates; Desired \& observed qualities; Private schools; Professional knowledge \& skills; Values \& attitude

\section{INTRODUCTION}

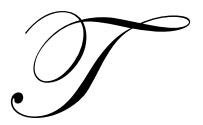

he quality of education in an educational institution depends upon the quality of teacher, which in turn depends on the quality of teacher education. Overall question of quality is directly related to the quality of teachers (Sultana et al., 2009) The standard of education can be improved by preparing competent and effective teachers (Bhat and Ganihar, 2006). Teacher training must consider market mechanisms to improve the programs and be responsive to consumers (Finkelstein \& Grubb, 2000). Pakistan is an example of a country that has both public and private sector educational institutions, a larger proportion of its youth is attending private institutions. The quality of these institutions depends more upon the quality of its staff than upon any other factor. As a part of management functions, recruiting and selecting teachers is considered an important task and an opportunity to improve instructional programs that will more likely influence student learning and achievement in a positive manner (Ghysels, 1988). The teacher recruitment at privately managed schools has been the focus for school management. The criteria of quality for teacher candidate are no simple task, though, because the criteria for doing so vary from person to person, from one community to another and from one era to the next.

The role of teacher is changing so fast that no teacher training can probably cope with the fast changing expectations of the society and school management (Singh, 2005). Most teachers lack commitment, motivation and preparedness (Qureshi, 2000). Career and Services (2004) gave a list of qualities employers look for in a teacher 
candidate. (1) Positive - Thinks positively and enthusiastically (2) Communicative - (3) Dependable (4) Personable - Establishes and maintains positive mutual working relationships (5) Organized (6) Committed (7) Motivational (8) Compassionate (9) Flexible (10) Individually Perceptive (11) Value Based - (12) Knowledgeable (13) Versatile, innovative, and open to new ideas. (14) Patient (15) Sense of Humor. More over experience is considered an important additional characteristic as schools find easy inducting such teachers.

Cockrill (1983) proposed following essential potential of teacher candidates that can be kept forth at selection process:

$\begin{array}{ll}\text { - } & \text { Interest in children } \\ \text { - } & \text { Emotional stability } \\ \text { - } & \text { Ability to communicate with pupils } \\ \text { - } & \text { Ability to get along with pupils } \\ \text { Enthusiasm fo maintain classroom discipline }\end{array}$

Jacobson \& Pecheone (1991) highlighted following ten indicators and abilities that can be observed for assessment process of teacher candidates:

- Can promote a positive learning environment.

- $\quad$ Can maintain appropriate standards of behavior.

- $\quad$ Can engage the students in meeting the objectives of the lesson.

- $\quad$ Can effectively manage routines and transitions.

- $\quad$ Can create a structure for learning.

- $\quad$ Can develop the lesson effectively, using appropriate instructional techniques.

- $\quad$ Can present appropriate content.

- $\quad$ Can use appropriate questioning techniques.

- $\quad$ Can communicate clearly, using precise language and acceptable oral expressions.

- $\quad$ Can monitor students' understanding of the lesson and adjusts teaching when appropriate.

The management of private educational institutions generally uses limited information, much of which is obtained from the perceptions and opinions of others found in application materials, personal interviews, and telephone reference checks (Moore, 1987). The personnel of private institutions place greatest value on the oral interview for selection process of teacher candidates. Vanderheiden (1982) found that for recruitment and selection procedures both structured and unstructured interviews were being used. Armstrong (1988) determined that the interview was the single most important tool in the selection process despite the fact that many questioned its importance. During the job interview the personal impression job candidates leave on potential school management seemed to be the most influential consideration in the administrative hiring decision. The least important consideration was family ties in the community or school. Another relatively less important trait was a sizable number of personal and situational characteristics such as gender, minority group status, and marital status (Seiferth \& Purcell 1979). Factors considered most important in recruitment of teachers were the letters of reference by the cooperating teacher, college supervisor, and building principal for the candidate's student teaching center, and the candidate's grade in student teaching (Mortaloni, 1984).

In Pakistan the private sector employers are not satisfied with the performance of young trained teachers. As they lack the personal qualities which the employers are seeking for. Perhaps few studies have been carried out in Pakistan about market based Teacher training. There is a need to study the qualities of teachers which employers seek for in their employees as teachers. The present study was designed to investigate the expected and observed levels qualities of teachers under three dimensions of educational and professional knowledge; dimensions of teaching and professional skills; and dimensions of values and attitudes. 


\section{OBJECTIVES OF THE STUDY}

The objectives of the study were:

- $\quad$ To investigate the personal qualities desired by the market.

- $\quad$ To investigate the perception of employers about the qualities possessed by trained teachers.

- $\quad$ To investigate the desired and observed levels for dimensions educational and professional knowledge; dimensions of teaching and professional skills; and dimensions of values and attitudes among teacher candidates.

\section{RESEARCH DESIGN}

Researchers undertook interviews, a focus group discussion and a survey as the research method. The entailed review of relevant literature was followed by a semi-structured interview with 20 employers of private educational institution. From this researchers constructed the initial three levels of dimensions of qualities for teacher candidates, which were dimensions of educational and professional knowledge; dimensions of teaching and professional skills; and dimensions of values and attitudes.

After this researchers invited the employers to participate in a focus group discussion. The topic of this focus group discussion was to identify the desired qualities of teacher candidates under three dimensions. In this way six qualities for each dimension were finalized. Then survey was conducted to rate the desired and observed levels of 18 items. A total number of 139 responses were available through this survey. The mean of desired and observed responses for each item was calculated. The difference between means, standard deviations and $\mathrm{t}$-values were also calculated.

\section{RESULTS}

Table 1: Dimensions of educational and professional knowledge

\begin{tabular}{|c|c|c|c|c|c|c|c|c|}
\hline \multirow{2}{*}{$\begin{array}{l}\text { Sr. } \\
\text { No. }\end{array}$} & \multirow{2}{*}{ Variable } & \multicolumn{2}{|c|}{ Desired } & \multicolumn{2}{|c|}{ Observed } & \multirow{2}{*}{$\begin{array}{l}\text { Difference } \\
\text { in Means }\end{array}$} & \multirow{2}{*}{$\mathbf{t}$} & \multirow{2}{*}{$\mathbf{p}$} \\
\hline & & Mean & SD & Mean & SD & & & \\
\hline 1. & Professional subject matter knowledge & 4.60 & 69 & 4.16 & 1.05 & .44 & 5.08 & .00 \\
\hline 2. & Counseling knowledge & 4.71 & .51 & 4.02 & 1.04 & .69 & 7.50 & .00 \\
\hline 3. & New knowledge to subject & 4.70 & .52 & 4.15 & .94 & .55 & 7.46 & .00 \\
\hline 4. & Teaching materials selection and compilation & 4.66 & .58 & 3.93 & 1.07 & .73 & 7.66 & .00 \\
\hline 5. & Language proficiency & 4.73 & .48 & 3.84 & 1.02 & .88 & 10.4 & .00 \\
\hline 6. & General teaching principles & 4.78 & .46 & 3.87 & 1.15 & .91 & 9.22 & .00 \\
\hline
\end{tabular}

Table 1 shows the desired and observed levels of employers' perceptions for dimensions of educational and professional knowledge among teacher candidates. An investigation for desired and observed qualities under dimensions of educational and professional knowledge for teacher candidates shows that these desired qualities were reported very important with arithmetic averages varying between 4.60 and 4.78 and they have observed their level fairly with averages between 3.84 and 4.16. The difference between the averages of desired and observed levels of qualities show a variance between 0.46 and 0.91 . The employers have mentioned that they find the most significant 1difference for desired and observed level in the quality of 'General teaching principles' which is 9.22. The standard deviations calculated for the desired and observed levels for dimensions of teaching and professional skills among teacher candidates are respectively 0.46 to 0.69 and 0.94 to 1.15 .

Table 2 shows that average desired levels for the dimensions of teaching and professional skills vary between 4.50 and 4.79 and it has been observed that the employers give utmost importance to the quality of 'Instructional assessment'. The average observed levels for these qualities are between 3.27 and 4.08. The quality of 'Instructional improvement' has been found very important, has the lowest average of observed level with 3.27. The employers consider that, such quality was observed at the lowest in comparison to the other teaching and professional skills. 
Table 2: Dimensions of teaching and professional skills

\begin{tabular}{|c|c|c|c|c|c|c|c|c|}
\hline \multirow{2}{*}{$\begin{array}{l}\text { Sr. } \\
\text { No. }\end{array}$} & \multirow{2}{*}{ Variable } & \multicolumn{2}{|c|}{ Desired } & \multicolumn{2}{|c|}{ Observed } & \multirow{2}{*}{$\begin{array}{l}\text { Difference } \\
\text { in Means }\end{array}$} & \multirow{2}{*}{$\mathbf{t}$} & \multirow{2}{*}{$\mathbf{p}$} \\
\hline & & Mean & SD & Mean & SD & & & \\
\hline 1. & Professional skill-related knowledge & 4.62 & .54 & 4.01 & .94 & .61 & 7.83 & .00 \\
\hline 2. & Pedagogy application & 4.55 & .65 & 4.02 & .91 & .53 & 7.64 & .00 \\
\hline 3. & Research and innovation & 4.76 & .43 & 4.04 & 1.15 & .73 & 7.59 & .00 \\
\hline 4. & Instructional improvement & 4.50 & .70 & 3.27 & 1.31 & 1.23 & 11.58 & .00 \\
\hline 5. & Instructional assessment & 4.79 & .41 & 4.08 & 1.17 & .71 & 7.04 & .00 \\
\hline 6. & Problem solving & 4.71 & .54 & 3.91 & 1.03 & .79 & 8.64 & .00 \\
\hline
\end{tabular}

The standard deviations calculated for the desired and observed levels for dimensions of teaching and professional skills among teacher candidates are respectively 0.41 to 0.71 and 0.91 to 1.31 . It has been observed that, the employers' ratings on desired levels are more identical than those on observed levels.

Table 3: Dimensions of values and attitudes

\begin{tabular}{|c|c|c|c|c|c|c|c|c|}
\hline \multirow{2}{*}{$\begin{array}{l}\text { Sr. } \\
\text { No. }\end{array}$} & \multirow{2}{*}{ Variable } & \multicolumn{2}{|c|}{ Desired } & \multicolumn{2}{|c|}{ Observed } & \multirow{2}{*}{$\begin{array}{c}\text { Differences } \\
\text { in Means }\end{array}$} & \multirow{2}{*}{$\mathbf{t}$} & \multirow[b]{2}{*}{$\mathbf{p}$} \\
\hline & & Mean & SD & Mean & SD & & & \\
\hline 1. & Working attitude & 4.38 & .62 & 3.98 & .85 & .40 & 5.45 & .00 \\
\hline 2. & Life-long learning & 4.04 & .72 & 3.50 & .86 & .55 & 7.02 & .00 \\
\hline 3. & Professionalism & 4.39 & .73 & 3.97 & .90 & .42 & 5.57 & .00 \\
\hline 4. & Interpersonal communication & 4.37 & .70 & 3.97 & .90 & .40 & 5.29 & .00 \\
\hline 5. & Professional ethics & 4.19 & .67 & 3.62 & .78 & .58 & 7.97 & .00 \\
\hline 6. & Respect for others & 4.21 & .72 & 3.86 & .88 & .35 & 4.79 & .00 \\
\hline
\end{tabular}

It has been observed from table 3 that employers find the desired qualities of teacher candidate for dimension of values and attitudes at the arithmetic averages between 4.04 and 4.39, with levels varying between 'very' and 'quite'. The employers consider that they have observed these qualities at the arithmetical averages between 3.50 and 3.98 at the 'quite' level. The standard deviation values for the qualities of desired level vary between 0.62 and 0.73; and as for the observed levels, they are between 0.78 and 0.90 . The employers act more identical in their opinion on the desired levels of these qualities. According to the results of the t-test to determine whether there is a meaningful average difference between the desired level and the observed level for the qualities under dimensions of values and attitudes among teacher candidates, it has been perceived that there is a meaningful difference rate of 0.01 for all qualities. The desired levels attributed to the values and attitudes are higher than their average observed levels.

\section{CONCLUSIONS AND DISCUSSION}

General teaching principles was most desired quality required by employers among teacher candidates. The knowledge of general principles makes the newly appointed teachers the good practitioners and handle the classes of privately managed schools as per desired demands. Another reason for the teacher candidates' incompatibility may be the fact that, their observed/desired professional starting behaviours are not at the desired level. This research has been conducted to determine the levels of desired and observed qualities under three dimensions. As for other dimensions, the qualities should be determined and selection criteria for teacher candidates be improved, based on such qualities.

The employers express that the trained teachers possess the qualities of: good in planning as top rank followed by commitment to the teaching profession, ability to handle difficult students, continuous learners, concept clearance, good in communication skills, positive attitude towards teaching, new techniques of teaching, persistence, flexibility, and use of teaching aids. Life long learning among teacher candidates was least rated observed dimension of value and attitude. Teaching is last option of many young graduates in Pakistan so usually they are less committed to their profession; possess low degree of persistence less positive attitude towards teaching and their job satisfaction level is low. More incentives are needed to improve the situation. 
The differences in mean values for desired and observed levels for all three categories indicate that employers of private schools are not satisfied with the output of teachers training programs. In Pakistan teacher training like B.Ed. is one year program whereas its actual teaching duration is of nine months only, and the content area which is expected to teach in field remains neglected. It seems that the teaching skills are not focused properly in the training institutions. Practice teaching is also very short and normally it is conducted at government sector schools, which have totally different handling as compared to private schools. This is why the employers of private schools are not satisfied with the performance of the newly trained teachers. So the training institutions may observe the demands of private institutions and arrange practice teaching at such schools so that the newly trained teachers may fulfil the demand of the market. Recruitment efforts for future teachers should be based on extrinsic and intrinsic motivation as the pupil teachers pursuing careers in private sector education had extrinsic carrier choice motivation (Yousuf and Anwar, 2006).

The competence of teachers entering the profession is of concern to society in general, and specifically to those education bodies who employ teaching graduates (Huntly, 2004). Teachers have significant effects on pupils' achievements (Title, 1995), and the administration involved in selection process have direct impact on instructional system by selecting excellent teachers. So the aptitude may be tested at the time when the teachers are selected for training. In the modern world new techniques are given much importance to improve the learning of the students. So the trained teacher should equip with the modern techniques, which he can adopt according to the situation to make clear the concepts of their students. Until and unless a teacher is satisfied with his/her job h/she cannot perform at the optimum level. A liaison between teacher training institutions and the schools is necessary for improving teacher training. Need based content -cum-methodology approach is recommended for teacher training in Pakistan.

\section{AUTHORS INFORMATION}

Muhammad Imran Yousuf is working as Assistant Professor in Division of Continuing Education, Pir Mehr Ali Shah Arid Agriculture University, Rawalpindi, Pakistan. He did his M.Phil. in Teacher Education from Allama Iqbal Open University, Pakistan and Ph.D. in Education from University Institute of Education and Research, UAAR, Pakistan. E-mail: dr.imran@uaar.edu.pk

Naveed Sultana is presently working as post-doctoral fellow at UK. She is Assistant Professor in Department of Education, Allma Iqbal Open University, Pakistan. Se did her Ph.D. in Education from University Institute of Education and Research, UAAR, Pakistan. E-mail: drnaveeda@gmail.com

Muhammad Naseer-ud-Din is working as Assistant Professor in Department of Education, Kohat University of Science and Technology, Kohat, Pakistan. He did his Ph.D. in Education from University Institute of Education and Research, UAAR, Pakistan. E-mail: naseer_khanpk2000@yahoo.com

Sajid Rehman is working as Senior Secondary School Teacher in Department of Education, Govt. of Punjab School Wing, Pakistan. He did his Ph.D. in Education from University Institute of Education and Research, UAAR, Pakistan. E-mail: drsajid_rehman@yahoo.com

\section{REFERENCES}

1. Armstrong, C. (1 988). Interview advice: Grill teachers about their track records. The Executive Educator, 14(9), 29.

2. $\quad$ Bhat, K.V and Ganihar N.N.(2006) . Total quality culture in teacher education colleges. New Delhi: Mahaveer \& sons.

3. Career and Services. (2004). What New Educators Need to Know about Teacher Qualities. .Teacher Qualities. Data Retrieved on October 7, 2007 from https://uwec.edu/career/students/jobsearch/teachers/teacherqualities.htm

4. Cockrill, J. E. (1 983). Procedures and criteria used by Texas public school administrative personnel specialists in the selection of teachers (Doctoral dissertation, East Texas State University, 1982 ). Dissertation Abstracts International, 43, 3467-A. 
5. Finkelstein, N.D. and W. N. Grubb (2000). Making Sense of Education and Training Markets: Lessons from England. American Educational Research Journal, 37(3), 601-631.

6. Ghysels, M. (1 988). A study of the perspectives, assumptions, and beliefs of school administrators towards teacher lesson demonstrations within the context of the teacher selection process. Unpublished master's thesis. California State University at Hayward, Hayward, CA.

7. Huntly, H. (2004) Beginning Teachers' Conceptions of Competence, Journal of College Teaching \& Learning, 1(5), 29-30.

8. Jacobson, L. S., \& Pecheone, R. L. (1991). Connecticut teacher assessment center (CON NTAC) program: Assessing professional knowledge of beginning teachers. Journal of Personnel Evaluation in Education, 5(2), 205-226.

9. Moore, A. J. (1 987). Selecting outstanding faculty: Indicators of quality. Journal of Teacher Education, 38(1), 43-47.

10. Mortaloni, R. (1984). School administrators evaluate the letter of reference and selected recruitment practices. Phi Delta Kappan, 58(7), 28-36.

11. Qureshi, M.A.(2000). Towards Education. Lahore: Dogar Publications.

12. Seiferth, B. \& Purcell T.D. (1979). Administrators' criteria for hiring practices. (ERIC Document Reproduction Service No. ED177096).

13. Singh, Y.K.(2005).Teacher Education. New Delhi: A.P.H. Publishing Corporation.

14. Sultana, N. Yousuf, M.I., Naseer-ud-Din, M., Rehman, S. (2009). The higher the quality of teaching the higher the quality of education. Contemporary Issues in Education Research. 2(3), 59-60.

15. Title, D. G. (1995). How to hire a teacher. Sacramento, CA: AASPA.

16. Vanderheiden, D. L. (1982). A study of the processes utilized in recruitment and selection of teachers in selected school districts: A planning model (Doctoral dissertation, The University of Nebraska - Lincoln, 1982). Dissertation Abstracts I nteonational, 42, 4683-A.

17. Yousuf, M.I., Anwar, M.N. (2006). Pupil teachers' motivation and behaviour towards the choice of government or private sector education as career. GCU Economic Journal, 39(2) 59-66. 